\section{The effect of physiological oxygen levels on GABAergic neuronal differentiation from mouse embryonic stem cells}

\author{
Eunju Shin, ${ }^{1,2}$ Nicholas R. Forsyth, ${ }^{1}$ \\ Rosemary A. Fricker ${ }^{1}$ \\ 'Institute for Science and Technology \\ in Medicine, Keele University, UK; \\ ${ }^{2}$ Wallenberg Neuroscience Center, \\ Division of Neurobiology, Lund \\ University, Sweden
}

\section{Abstract}

Embryonic stem cells (ESCs) have the ability to generate any kind of cell in the body. They, therefore, have great potential for use in cell therapies for neurodegenerative disorders such as Huntington's disease. Establishing a culture environment to mimic components of physiological conditions may help to maintain and differentiate ESCs more successfully. One of the important conditions is the level of oxygen. Traditionally, $20 \%$ oxygen $\left(\mathrm{O}_{2}\right)$ has been used to culture cells, but this is much higher than physiological levels $\left(\begin{array}{ll}2 \% & \mathrm{O}_{2}\end{array}\right)$. In this study, we used the mouse ESC line 46C (Sox1GFP knock-in) to investigate the effect of physiological oxygen on proliferation of mESCs, and their differentiation to neural progenitors (where Soxl is expressed) and mature GABAergic neurons. mESCs were cultured in either high $(20 \%, \mathrm{H})$ or low $(2 \%, \mathrm{~L})$ oxygen levels for four days before induction of differentiation, and subsequently differentiated under either high or low oxygen, in a $2 \times 2$ factorial design (H-H, H-L, L-H, L-L). mESCs placed in low oxygen levels during the differentiation phase showed less proliferation (a decreased proportion of Ki67+ cells), complete loss of the self-renewing population (Oct4+ cells), and a decrease in Sox-1+ neural precursors. Consistent with this, neurons generated under low levels of oxygen showed a more mature morphology with an increased number of primary neurites and increased levels of GABA neurotransmitter. There was no significant difference in the percentage of neurons generated from either condition. We conclude that mESC culture in low oxygen conditions promotes maturation during neuronal differentiation and helps eliminate the residual Oct $4^{+}$population. The adoption of low oxygen environments during neuronal differentiation may, therefore, decrease teratoma formation and increase the potential for ESC use in cell therapies for neurodegenerative disease.

\section{Introduction}

Embryonic stem cells (ESCs) have a great potential for use in cell therapies in neurodegenerative disorders such as Huntington's disease. Establishing a culture environment that is similar to physiological conditions may help ESC maintenance and differentiation. One important condition is the level of oxygen. The oxygen level of adult brain tissue ranges between 1 to $5 \%^{1-3}$ and is also low in the uterine environment (2-8\%).,5 Traditionally, $5 \% \mathrm{CO}_{2}$ and $95 \%$ of atmospheric air has been used for ESC culture, thus the oxygen level is $20 \%$, which is hyperoxic to cells. Hyperoxia can increase the number of reactive oxygen species within cells, which then can damage proteins, lipids, and nucleic acids. $^{6,7}$ Previous studies have reported that ESCs in physiological oxygen showed enhanced ESC clonal recovery and decreased chromosomal abnormalities. ${ }^{8,9}$ In addition, both human and mouse ESCs retained an undifferentiated phenotype when appropriate signals were given in low $\mathrm{O}_{2}$ conditions, whereas, in the same culture, medium in high (20\%) $0_{2}$, parts of ESC colonies began to lose expression of their pluripotency marker Oct4. ${ }^{10,11}$ In other studies, under low $\mathrm{O}_{2}$ conditions, cortical, ganglionic eminence (GE), and ventral mesencephalic (VM) precursor/stem cells showed increased proliferation when they were incubated with mitogens. ${ }^{12-17}$ In addition, the culture of human and mouse VM precursors in low $\mathrm{O}_{2}$ has been shown to lower cell death and delay senescence. ${ }^{13,18}$ When differentiation was induced, more tyrosine hydroxylase $(\mathrm{TH})^{+}$dopaminergic neurons were generated from rat VM cultures maintained in lowered $\mathrm{O}_{2}$ conditions ${ }^{12}$ and more $\mathrm{TH}^{+}$sympathoadrenal cells were generated from rat neural crest stem cells. ${ }^{19}$ In the case of GE cultures, the neurotransmitter phenotype was changed from GABAergic to glutamatergic after culture in low $\mathrm{O}_{2} \cdot{ }^{17}$ Recently, one study reported increased dopaminergic differentiation of mESCs using a 5-stage protocol in a $3.5 \%$ low $0_{2}$ level. ${ }^{20}$ In this study, mESCs were differentiated in high $\mathrm{O}_{2}$ until cells became neural progenitor. Then cells were exposed to low $\mathrm{O}_{2}$ during the neural progenitors expansion (stage 4) and neuronal differentiation (stage 5). Recently, Mondragon-Teran et al. reported the effect of low $\mathrm{O}_{2}$ on neuronal differentiation from mESCs. ${ }^{21}$ They found enhanced cell proliferation and neuronal differentiation during monolayer differentiation in low $\mathrm{O}_{2}$ although did not investigate which specific neurons were formed. There are no reports which describe how mESCs will respond to low $\mathrm{O}_{2}$
Correspondence: Rosemary A. Fricker, Schools of Medicine and Life Sciences, \& Institute for Science and Technology in Medicine, Huxley Building, Keele University, Keele ST5 5BG, UK. Tel. +44.01782.733874/734639 - Fax: +44.01782 733516 . E-mail: r.a.fricker@keele.ac.uk

Key words: mouse embryonic stem cells, low oxygen, neuronal differentiation, GABA.

Acknowledgments: we thank Dr. Meng Li in Imperial College London for providing mESC line 46C. This research was supported by funding from Keele Medical School, Keele University, UK.

Contributions: ES, conception, execution and analysis of the study, drafting and editing of the article; NRF, scientific advisor and editing of the article; RAF, research director, scientific advisor and editing of the article.

Conflict of interests: the authors declare no potential conflict of interests.

Received for publication: 19 January 2012

Revision received: 26 March 2012.

Accepted for publication: 27 March 2012.

This work is licensed under a Creative Commons Attribution NonCommercial 3.0 License (CC BYNC 3.0).

(C) Copyright E. Shin et al., 2012

Licensee PAGEPress, Italy

Stem Cell Studies 2012; 2:e3

doi:10.4081/scs.2012.e3

conditions during GABAergic neuronal differentiation. Therefore, in the present study, we investigated the effect of low $\mathrm{O}_{2}$ on GABAergic neuronal differentiation by exposing cells to a low $\mathrm{O}_{2}$ tension from the mESC proliferation stage to the end of the neuronal differentiation stage, using the monolayer method.

\section{Materials and Methods}

Unless stated otherwise, all reagents were from Sigma, UK (Sigma-Aldrich Corp., St. Louis, M0, USA).

\section{mESC culture}

The mouse ESC line $46 \mathrm{C}^{22}$ was used in this study. This ESC line contains a green fluorescent protein (GFP) and puromycin resistance construct driven by the Sox-1 promoter which is switched on during the neurectoderm phase of stem cell differentiation. To see the effect of a physiological level of oxygen on mESCs (passage 29-31), cells were cultured in either high (20\%) or low (2\%) oxygen levels for four days in proliferating conditions with one passage 
$\left(10^{6}\right.$ cells in a T25 flask with $10 \mathrm{~mL} 10 \%$ fetal calf serum and $100 \mathrm{U} / \mathrm{mL}$ LIF in GMEM; FCS/LIF) before being divided into two further groups and differentiated at either high or low oxygen levels (i.e. generating four experimental groups: H-H, H-L, L-H, L-L, Figure 1). mESCs were differentiated using the monolayer method which was first described by Ying et al..$^{23}$ and compared with other methods by Shin et al. ${ }^{24}$ Briefly, mESCs were plated onto $0.1 \%$ gelatin-coated dishes at a density of $10^{4}$ cells $/ \mathrm{cm}^{2}$ in $\mathrm{N} 2 \mathrm{~B} 27$ medium (1:1 mixture of DMEM/F12 (Invitrogen, Life Technologies Ltd., Paisley, UK) supplemented with modified $\mathrm{N} 2 ; 25 \mu \mathrm{g} / \mathrm{mL}$ insulin, $100 \mu \mathrm{g} / \mathrm{mL}$ apo-transferrin, $6 \mathrm{ng} / \mathrm{mL}$ progesterone, $16 \mu \mathrm{g} / \mathrm{mL}$ putrescine, $30 \mathrm{nM}$ sodium selenite, and 50 $\mu \mathrm{g} / \mathrm{mL}$ bovine serum albumin fraction $\mathrm{V}$; and neurobasal medium (Invitrogen) supplemented with B27 (Invitrogen). Medium was renewed every other day. On Day $7,3 \times 10^{4}$ dissociated cells in $30 \mu \mathrm{L}$ N2B27 medium with 1 $\mu \mathrm{M}$ retinoic acid (RA) were seeded on poly-Dlysine and laminin coated $13 \mathrm{~mm}$ glass coverslips (Fisher Scientific, Loughborough, UK). After 4-6 h, $500 \mu \mathrm{L}$ of the medium (N2B27+RA) was added, and this was replaced every other day for seven days. For some cultures, cells were cultured in N2B27 for ten days and then N2B27 and RA for a further seven days. In this condition, $0.5 \mu \mathrm{g} / \mathrm{mL}$ puromycin was added from Day 6 to Day 11 . For high $\mathrm{O}_{2}$ conditions, cells were incubated in a standard humidified incubator at $37^{\circ} \mathrm{C}$ in $5 \%$ $\mathrm{CO}_{2}$ and $95 \%$ air, whereas for low $\mathrm{O}_{2}$ conditions, cells were incubated in a modular incubator (RS Biotech, Irvine, UK) at $37^{\circ} \mathrm{C}$ in $5 \%$ $\mathrm{CO}_{2}, 2 \% \mathrm{O}_{2}$ and $93 \% \mathrm{~N}_{2}$. The levels of the $\mathrm{O}_{2}$ and $\mathrm{CO}_{2}$ were monitored constantly. $\mathrm{N}_{2}$ gas was supplied from a NG400A Nitrogen Generator (Peak Scientific, UK).

\section{Immunocytochemistry and data analysis}

All cultured cells were fixed by washing with phosphate buffered saline (PBS) followed by $20 \mathrm{~min}$ in $4 \%$ paraformaldehyde at $4^{\circ} \mathrm{C}$. Fixed cells were permeabilized with $100 \%$ ethanol for $2 \mathrm{~min}$ at room temperature and rinsed 3 times with PBS. Non-specific binding was blocked in 5\% normal goat serum (NGS, DAK0, Ely, UK) for $1 \mathrm{~h}$ at $4^{\circ} \mathrm{C}$. Cells were incubated overnight at $4^{\circ} \mathrm{C}$ in $1 \%$ NGS containing primary antibodies (mouse anti- -III-tubulin, 1:400; Rabbit anti-GFP, 1:500, Chemicon, Millipore Corp., Billerica, MA, USA; mouse anti-0ct4, 1:100, Santa Cruz Biotechnology, Santa Cruz, CA, USA; rabbit anti-GABA, 1:750; rabbit anti-Ki67, 1:500, AbCam, Cambridge, UK). The next day, cells were washed 3 times with PBS and incubated with secondary antibodies (Goat anti-rabbit 546 or 488 and Goat anti-mouse 546 or $488, \quad$ 1:200 each,

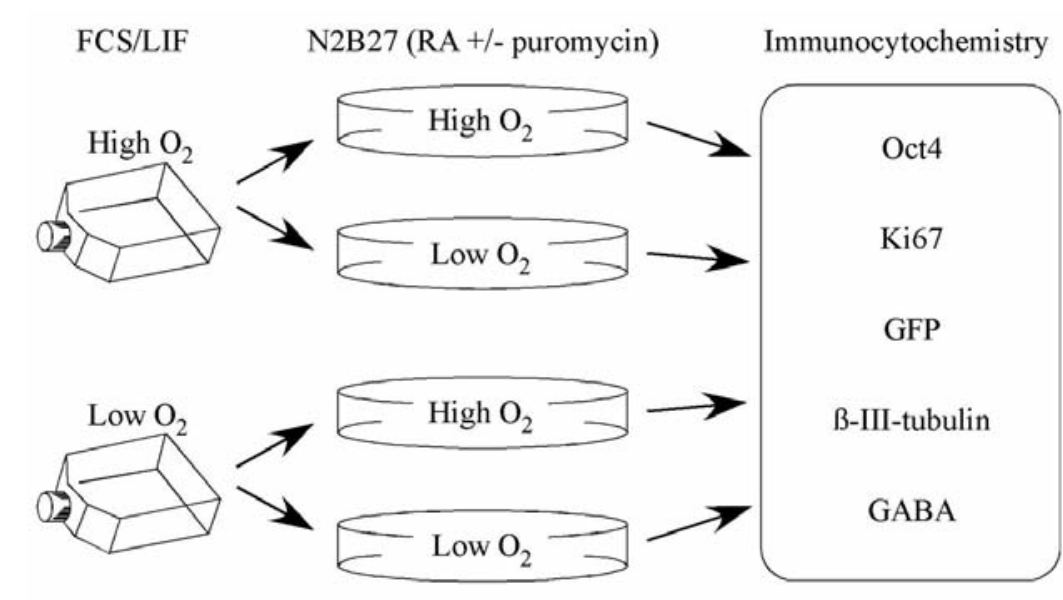

Figure 1. Experimental design. Mouse embryonic stem cells were expanded in either high or low $\mathrm{O}_{2}$ conditions for four days in fetal calf serum/LIF medium before being split into two groups. After differentiation in the N2B27 medium with retinoic acid for 14 (without puromycin) to 17 (with puromycin) days, cells underwent immunocytochemistry using various antibodies.

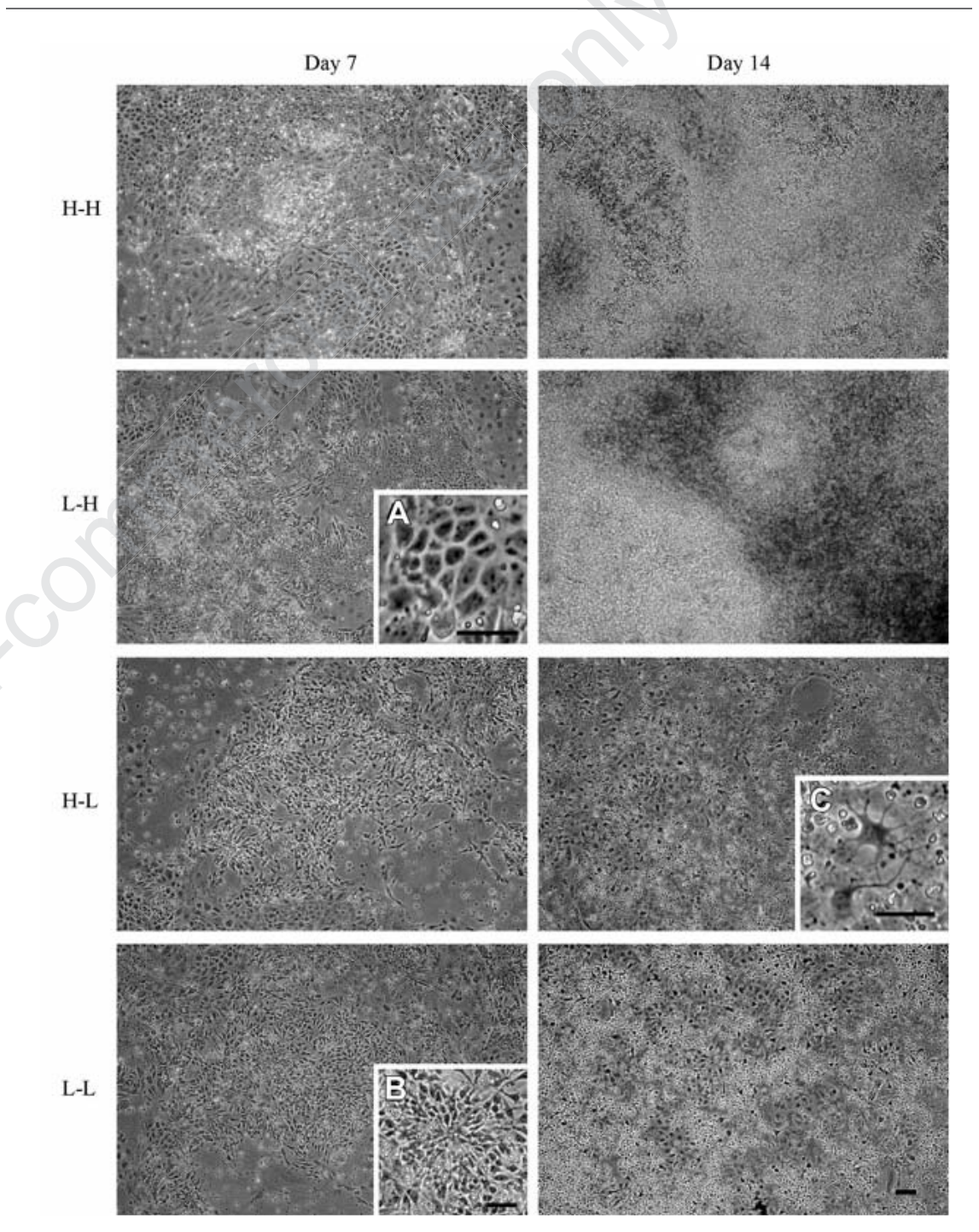

Figure 2. Live images of Day 7 and day 14 cultures in 4 conditions. Cells were cultured in N2B27 for seven days and replated on Day 7. Day 7 images were taken before trypsinisation. Cells were further cultured in N2B27 and RA for seven days. Day 14 images were taken before fixation on Day 14 . Scale bar $100 \mu \mathrm{m}$ applies to all low magnification pictures. Scale bars in inserts $40 \mu \mathrm{m}$. 
Invitrogen) in $1 \% \mathrm{NGS}$ for $2 \mathrm{~h}$ at $4^{\circ} \mathrm{C}$. After 3 PBS washes, coverslips were mounted using Vectashield hardset mounting medium containing DAPI (Vector Laboratories, Peterborough, UK).

After immunostaining, cells were viewed using a Nikon Eclipse 80i microscope and images were acquired with a Hamamatsu ORCA camera using NIS Elements imaging software (Nikon Corp., Tokyo, Japan).

Images were captured using equivalent intensity settings and the fluorescence intensity for $\mathrm{GFP}^{+}$and $\mathrm{GABA}^{+}$cells was measured using the NIS image software. Cells were classed as having strong expression of GFP at a quantitative fluorescence calibration intensity threshold of 200 or more. Strong expression was usually in the intensity range of 240 260. Weak GFP expression was most commonly seen at levels of 160-180.

Similarly, for GABA intensity, the threshold for classification as strong expression was set at a quantitative fluorescence calibration of 200 or more. Strong $\mathrm{GABA}^{+}$cells usully fell in the range of $220-260$, and $w e a k \mathrm{GABA}^{+}$cells in the range 100-150. Three independent experiments were carried out and three coverslips were examined for each condition in each experiment to measure specific cell population and neurites. For all data analysis, one way ANOVA and Tukey's multiple comparison test were employed (GraphPad Prism version 4.00). $\mathrm{P}<0.05$ was considered significant.

\section{Results}

\section{The proliferating population was} decreased in cells exposed to low $\mathrm{O}_{2}$ conditions during the differenti-

\section{ation period}

When cells were counted using trypan blue exclusion before replating on coverslips, at Day 7 , there was no significant difference in the number of viable cells between groups (data not shown). However, mESCs cultured in high $\mathrm{O}_{2}$ during the later half of the differentiation period (Days 8-14) produced more total cells than populations differentiated in low $\mathrm{O}_{2}$ conditions (Figure 2). In addition, the colonies in high $\mathrm{O}_{2}$ conditions appeared more 3 -dimensional, with packed cells, often attributed to faster-dividing pluripotent cells.

Therefore, the cell division marker Ki67 was used to detect proliferating cells at Day 14. mESCs in high $\mathrm{O}_{2}$ showed significantly higher numbers of proliferating cells compared to those in low $\mathrm{O}_{2}$ although the proportion of proliferating cells in the cultures was fairly modest (Figure 3A-C, ANOVA: $\mathrm{F}_{3,8}=20.36, \mathrm{P}<0.001$ ).

\section{$\mathrm{Oct}^{+}$cells were removed com- pletely in low $\mathrm{O}_{2}$ conditions}

Cells were cultured in N2B27 for seven days. On Day 7, cells were replated on coverslips and cultured for a further seven days before fixation. Figure 2 shows images from the 4 conditions ( $\mathrm{H}-\mathrm{H}, \mathrm{L}-\mathrm{H}, \mathrm{H}-\mathrm{L}$, and $\mathrm{L}-\mathrm{L})$ on Day 7 and a further seven days after replating (Day 14). On Day 7, neural rosettes were observed throughout the cultures (Figure 2, insert B). However, L-L and H-L cultures contained more neurallike cells than $\mathrm{H}-\mathrm{H}$ and $\mathrm{L}-\mathrm{H}$ cultures. In $\mathrm{H}-\mathrm{H}$ and L-H cultures, epithelial-like cells (Figure 2, insert A) were more abundant than in L-L and H-L cultures. On Day 14, H-H and L-H cultures were denser than L-L and H-L cultures and,

A
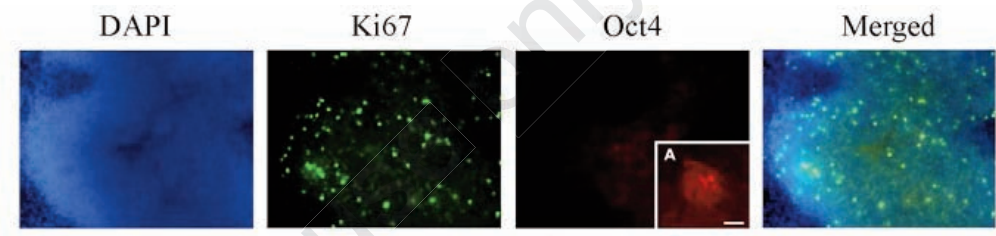

-H
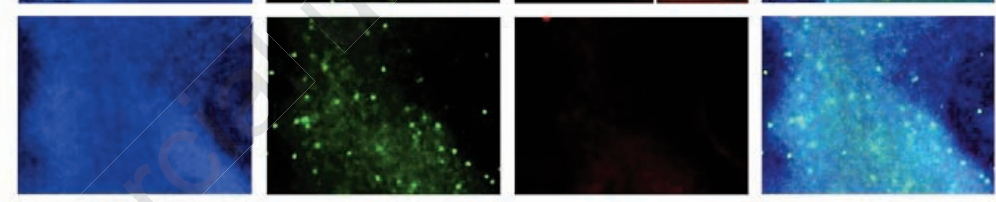

H-L
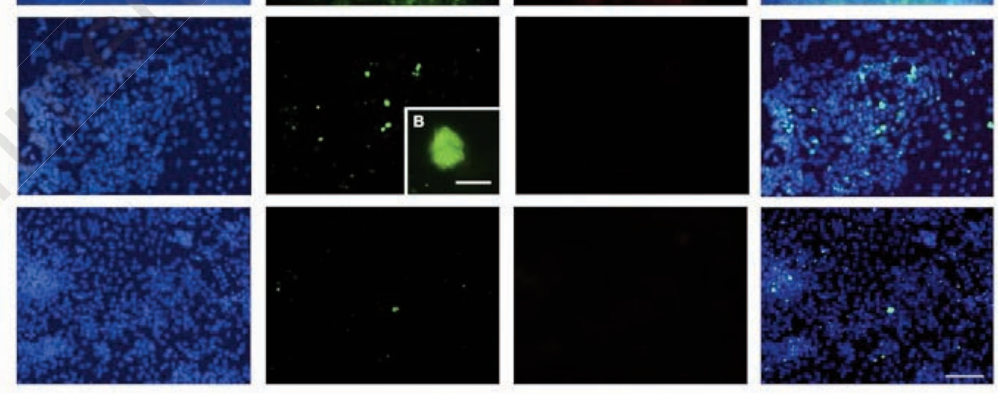

B
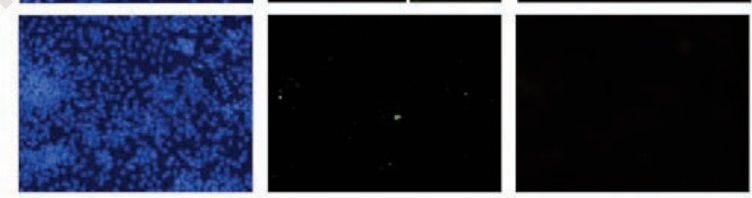

C
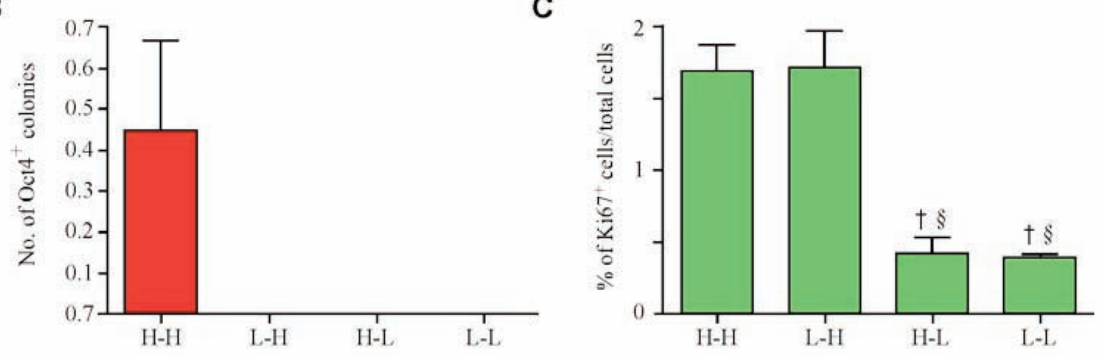

Figure 3. Effect of low $\mathrm{O}_{2}$ on the pluripotent cell population and proliferative cell population during differentiation. Cells were cultured for 14 days and stained. (A) Immunocytochemistry of Oct4 and Ki67. An example of an Oct $4^{+}$colony. (B) A Ki67 ${ }^{+}$cell. Scale bar in the last merged picture is $100 \mu \mathrm{m}$ and applies to all low power images. The scale bar in (A) is $20 \mu \mathrm{m}$ and the scale bar in (B) $10 \mu \mathrm{m}$. (B) The number of Oct $4^{+}$colonies per coverslip. Data was not significantly different. However, there were zero Oct $4^{+}$cells in low $\mathrm{O}_{2}$ conditions. (C) Percentage of $\mathrm{Ki}^{6} 7^{+}$cells over total cells. The proliferating population was significantly reduced in cultures incubated in low $\mathrm{O}_{2}$ during the neuronal differentiation period. $\uparrow, \mathrm{P}<0.01$ compared to $\mathrm{H}-\mathrm{H} ; \S, \mathrm{P}<0.01$ compared to $\mathrm{L}-\mathrm{H}$. 


\section{The Sox1-GFP ${ }^{+}$cell population was} decreased in low $\mathrm{O}_{2}$ conditions

Next, all non-neuronal cells were removed using puromycin and RA treatment to allow easier visual examination of the neural cells which had formed. ${ }^{24}$ Cells were cultured in N2B27 for ten days and puromycin was applied in the medium from Day 6 to Day 10 (Figure 4). Compared to non-purified cultures (Figure 2, Day 7), non-neural looking cells were dramatically decreased and in all 4 conditions many neural rosettes were found (Figure 4, arrows). 0n Day 10, cells were replated on coverslips and cultured for seven more days. Compared to non-purified cultures (Figure 2, Day 14), the number of cells was substantially reduced in all 4 conditions and neuron-looking cells were more frequently and easily seen (Figure 5). In particular, cells in low $\mathrm{O}_{2}$ during differentiation (i.e. H-L and L-L) showed mature and healthy looking morphologies (Figure 5, arrows) compared to those in high $\mathrm{O}_{2}$ (H-H and L-H).

After seven days on coverslips, cells were labeled with 0ct4 and GFP antibodies. There were no $0 c t 4^{+}$pluripotent cells present in any condition $(\mathrm{n}=3)$, whereas GFP was expressed by the majority of cells to varying degrees. Some cells expressed much higher levels of GFP (Figure 6A, white arrow) than others (Figure 6A, yellow arrow); therefore, expression was quantified both to determine how many cells were expressing GFP regardless of expression intensity and also how many expressed only high levels of GFP. It was hypothesized that the strong GFP expression would be true Sox $1^{+}$neural precursor cells, and weakly expressing cells would be young neurons and glial cells which contained remnant GFP protein even though their GFP gene had been switched off, since GFP protein (half-life up to $26 \mathrm{~h}$ ) tends to remain longer in the cell than the gene expression. ${ }^{25}$ There was no significant difference in percentage of total GFP expressing cells (disregarding expression intensity) between groups (ANOVA: $\mathrm{F}_{3,8}=0.4588$, n.s.; Figure $6 \mathrm{~A}$ and $\mathrm{B}$ ). However, there were significantly fewer cells which were expressing high levels of GFP in the low $\mathrm{O}_{2}$ cultures during differentiation (i.e. $\mathrm{H}-\mathrm{L}$ and $\mathrm{L}-\mathrm{L}$ ) compared to cells differentiated in high $\mathrm{O}_{2}$ conditions (i.e. $\mathrm{H}-\mathrm{H}$ and L-H) (ANOVA: $\mathrm{F}_{3,8}=11.76$, $\mathrm{P}<0.01$; Figure $6 \mathrm{~A}$ and $\mathrm{C}$ ).

\section{Neurons in low $\mathrm{O}_{2}$ conditions}

\section{showed a more mature morphology than in high $\mathrm{O}_{2}$ conditions}

After 17 days in differentiation culture, cells were stained with TUJ1 and GABA antibody. Since cells in low $\mathrm{O}_{2}$ cultures showed a more mature morphology, we considered whether neuronal differentiation was accelerated, thus producing more neurons. On investigation, there was no significant difference in the percentage of $\mathrm{TUJ}^{+}$neurons between groups (ANOVA: $\mathrm{F}_{3,8}=0.018$, n.s.; Figure 7A and B).

The number of primary neurites was counted on 30-60 neurons per coverslip in each condition. As seen previously in the live images, neurons cultured in low $\mathrm{O}_{2}$ (i.e. $\mathrm{H}-\mathrm{L}$ and $\mathrm{L}-\mathrm{L}$ ) possessed significantly more primary neurites than neurons cultured in high $\mathrm{O}_{2}$ conditions (i.e. $\mathrm{H}-\mathrm{H}$ and L-H) (ANOVA: $\mathrm{F}_{3,8}=11.62, \mathrm{P}<0.01$; Figure $7 \mathrm{~A}$ and $\mathrm{C}$ ). GABAergic neuronal differentiation in high and low $\mathrm{O}_{2}$ conditions was then investigated. Like GFP immunoreactivity, GABA labeling showed two different intensities: strong fluorescence (Figure 7A, white arrow) or more weak fluorescence (Figure 7A, yellow arrow). Therefore, we first quantified $\mathrm{GABA}^{+}$neurons over total neurons regardless of staining intensity. The majority of neurons were GABAergic $(70-75 \%)$ and the percentage was similar between groups (ANOVA: $\mathrm{F}_{3,8}=0.995$, n.s.; Figure 7A and D). However, when we compared strongly stained GABAergic neurons (considered to be mature GABAergic neurons since strong staining reflects more
GABA content), the percentage of more mature GABAergic neurons was increased in cultures differentiated in low $\mathrm{O}_{2}$ conditions (i.e. $\mathrm{H}-\mathrm{L}$ and $\mathrm{L}-\mathrm{L}$ ) compared to high $\mathrm{O}_{2}$ conditions (i.e. $\mathrm{H}-\mathrm{H}$ and L-H) (ANOVA: $\mathrm{F}_{3,8}=156.1, \mathrm{P}<0.0001$; Figure $7 \mathrm{~A}$ and $\mathrm{E}$ ); this was consistent with the results of neurite number. In addition, compared to high $\mathrm{O}_{2}(\mathrm{H}-\mathrm{H})$, low $\mathrm{O}_{2}$ cultures ( $\mathrm{L}-\mathrm{H}$, $\mathrm{H}-\mathrm{L}$, and $\mathrm{L}-\mathrm{L}$ ) tended to contain more evenly dispersed neurons across the coverslips (Figure 7, 10x TUJ1).

\section{Discussion}

We investigated the effect of low oxygen on mESC differentiation to GABAergic neurons together with cell proliferation and pluripotency. Here, we used the monolayer method to differentiate mESCs, based on previous findings that these stem cells differentiate into functional GABAergic neurons, expressing appropriate markers, and possessing functional electrophysiology similar to medium spiny GABAergic projection neurons in the develop-

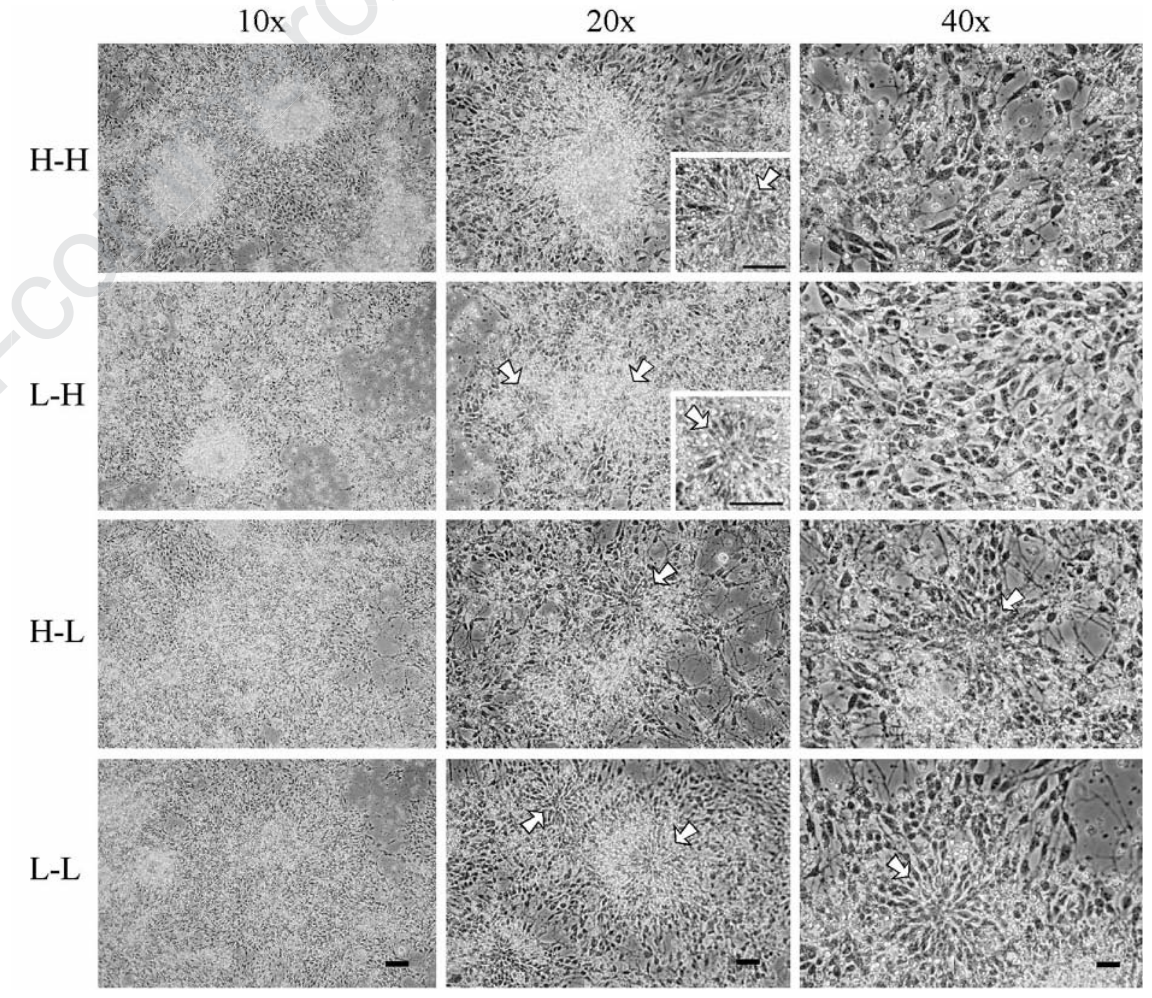

Figure 4. Day 10 cultures in 4 conditions. Cells were cultured in N2B27 for ten days. Puromycin was applied in the medium from Day 6 to Day 10. Many non-neural cells were removed and most of the cells appeared as neural rosettes (arrow) or bipolar cells. Scale bars in the first column $(10 x) 100 \mu \mathrm{m}$, in the second column including those in inserts (20x) $50 \mu \mathrm{m}$, and the last column (40x) $25 \mu \mathrm{m}$. 
ing striatum. ${ }^{24}$ We exposed cells to low (2\%) and high (20\%) oxygen tension first during the proliferating/undifferentiated stage in the presence of FCS and LIF and then we further split cultures into low and high $\mathrm{O}_{2}$ conditions when differentiation was induced. The exposure to low $\mathrm{O}_{2}$ during the proliferating/undifferentiated stage had a positive effect on removal of $0 \mathrm{ct} 4^{+}$pluripotent cells since $\mathrm{H}-\mathrm{H}$ cultures very rarely showed $0 \mathrm{ct} 4^{+}$colonies, but in $\mathrm{L}-\mathrm{H}$ cultures there were no $\mathrm{Oct}^{+}{ }^{+}$colonies in any of the three independent cultures analyzed in triplicate. However, the populations of Ki67+ mitotic cells, Soxl-GFP+ neural precursors, $\mathrm{TUJ1}^{+}$neurons, and GABAergic neurons were not affected by low $\mathrm{O}_{2}$ tension during the proliferating/undifferentiated stage. These populations were more affected by low $\mathrm{O}_{2}$ exposure during the differentiation stage (i.e. $\mathrm{H}-\mathrm{H} v s \mathrm{~L}$ $\mathrm{H}$, and $\mathrm{H}-\mathrm{L} v s \mathrm{~L}-\mathrm{L}$ did not show any significant differences; but $\mathrm{H}-\mathrm{H} v s$ H-L and L-H $v s$ L-L did show significant differences). This may reflect the short incubation period in low $\mathrm{O}_{2}$ in the presence of FCS/LIF, since mESCs were cultured in FCS/LIF medium under low $\mathrm{O}_{2}$ tension for only four days before starting differentiation. Therefore, four days might not be enough to see the full effect of low $\mathrm{O}_{2}$ and mESCs might need to be cultured for a longer period in FCS/LIF conditions or even be derived in low $\mathrm{O}_{2}$ conditions. Previous studies have reported that low oxygen tension favors proliferation and survival of stem/progenitor cells during their expansion period in embryonic rat and human VM progenitors, ${ }^{12,13,18,26}$ human neonatal subventricular zone cells, ${ }^{16}$ embryonic rat cortical cells, ${ }^{15,27}$ embryonic rat GE cultures, ${ }^{17}$ and embryonic rat neural crest stem cells. ${ }^{19}$ Also in some studies using undifferentiated mESCs, low $\mathrm{O}_{2}$ promoted proliferation of mESCs. ${ }^{9,28}$

Interestingly, previous research has shown that mESCs that were kept in low $\mathrm{O}_{2}$ for 18 months but then once returned to higher $\mathrm{O}_{2}$ conditions behaved very similarly to mESCs cultured in high $\mathrm{O}_{2}$ throughout the study. ${ }^{11}$ Forsyth et al. reported similar results from hESC cultures. ${ }^{8}$ In low $0_{2}$, hESCs formed colonies more efficiently than in high $\mathrm{O}_{2}$. When hESCs were re-oxygenated from 2 to $21 \% \mathrm{O}_{2}$ they did not form colonies as efficiently as those in low $\mathrm{O}_{2}$ or, interestingly, with similar efficiency as those cultured in $21 \%$ throughout. We did not examine the number of Ki67+ cells of mESCs during the proliferation stage, therefore, we cannot conclude whether proliferation in low $\mathrm{O}_{2}$ conditions leads to increased or lowered numbers of dividing stem cells. However, it appears from previous studies that culturing cells in low $\mathrm{O}_{2}$ during the proliferation period might not affect differentiation to a significant extent, and lowering the oxygen tension only during the differentiation period may be more effective in influencing ESC fates. In this study, low oxygen tension during the differentiation period (i.e. H-L and L-L) lowered the number of Ki67+ ${ }^{+}$proliferating cells. This agrees with a previous report in which the number of mESC-derived EBs was less in cultures placed in $5 \% \mathrm{O}_{2}$ compared with 20 and $40 \% \mathrm{O}_{2} \cdot{ }^{29}$ In addition, hESC-derived EBs were shown to have slower proliferation in 1 and $5 \% \mathrm{O}_{2}$ tension compared to $20 \% \mathrm{O}_{2}$ tension. ${ }^{30}$ This is important when considering transplantation of ESC-derived neurons, as the introduction of cells that maintain the propensity to divide has been linked with teratoma formation by grafted cells. One recent study reported a similar experimental approach to the current study here. ${ }^{21}$ Researchers differentiated E14Tg2a mESCs (the parental mESC line for $46 \mathrm{C} \mathrm{mESCs}$, which were used in the current study) for eight days using the mono- layer method in low (2\%) and high (20\%) $\mathrm{O}_{2}$ and then looked at cell proliferation by counting viable cells and the expression levels of nestin, TUJ1 and MAP2 by immunocytochemistry and flow cytometry. Authors found that there was increased live cell density at Day 8 in low $\mathrm{O}_{2}$ conditions compared with high $\mathrm{O}_{2}$. This is different to the current study, where cells at Day 7 showed no obvious difference in cell density (Figure 2, first column). The difference in findings might come from assessing the live cells at different time points during their differentiation. According to the same paper, ${ }^{21}$ the viability of the cells goes down dramatically after Day 7. Also, differences in the seeding cell density might have affected the live cell density on Days 7 and 8.

Mondragon-Teran et al. found significantly more neural rosettes in low $\mathrm{O}_{2}$ cultures (3- fold increase), ${ }^{21}$ and the current study also found neural rosettes more easily in low $\mathrm{O}_{2}$ condi-

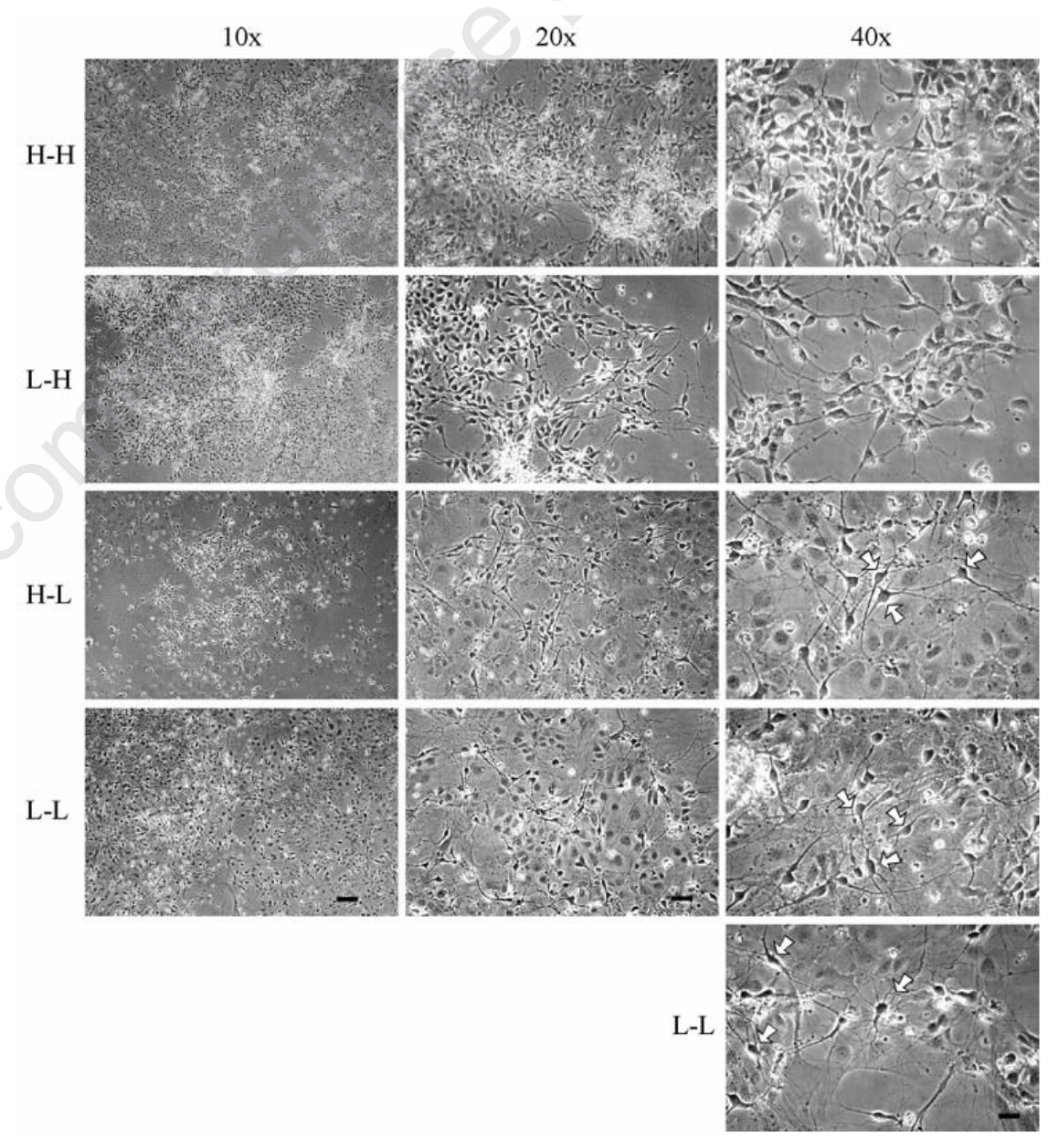

Figure 5. Day 17 cultures from the four conditions. Cells were cultured in N2B27 for ten days. Puromycin was applied in the medium from Day 6 to Day 10. On Day 10, cells were replated and further cultured in N2B27, puromycin, and RA for two days and without puromycin for five days. Cells developed into mature looking neurons (arrows) and glial cells. Scale bar in the first column $(10 x) 100 \mu \mathrm{m}$, second column $(20 x) 50 \mu \mathrm{m}$, and last column (40x) $25 \mu \mathrm{m}$. 
tions. In the previous study, nestin ${ }^{+}$neural precursors were slightly decreased in low $\mathrm{O}_{2}$ conditions whereas $\mathrm{TUJ1}^{+}$neurons and $\mathrm{MAP2}^{+}$ neurons were increased in low $\mathrm{O}_{2}$ condition. In the current study, Sox1-GFP+ neural conditions were decreased when examined on Day 14 of the differentiation protocol. Even though the time and the culture medium were slightly different in two studies, incubating differentiating mESCs in low $\mathrm{O}_{2}$ helped the progression of differentiation in both studies. However, unlike the study of Mondragon-Teran et al., there was no significant difference in the percentage of TUJ1+ neurons in the current study in low and high $\mathrm{O}_{2}$ cultures. One reason for this might be the different time point when the neuronal population was quantified. In the Mondragon-Teran et al. study, cells were cultured with N2B27 and neural cells were not selected from the total population. In the cur-
A
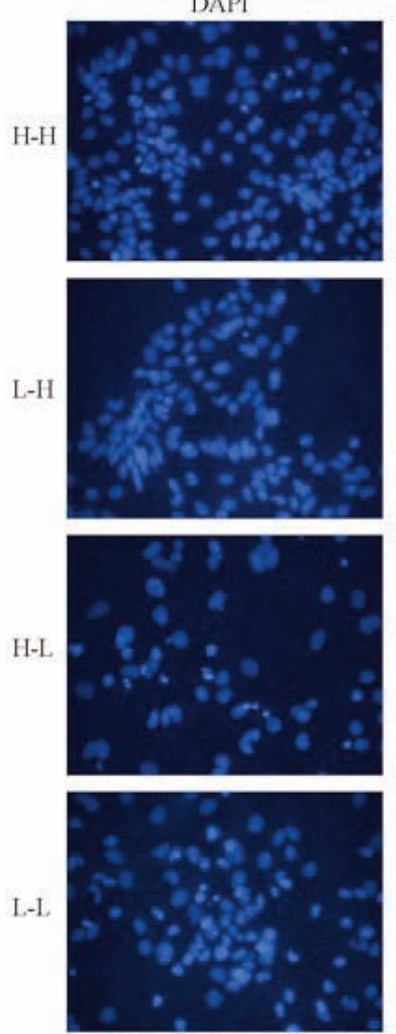

B

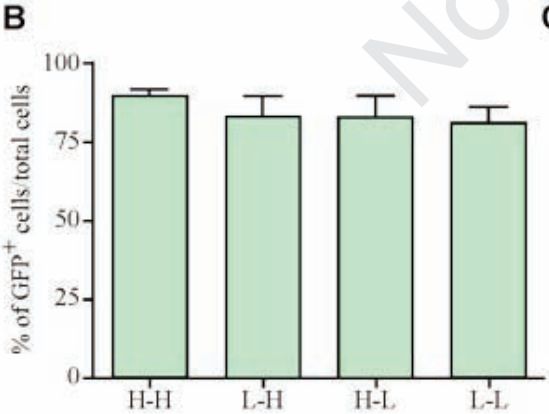

GFP
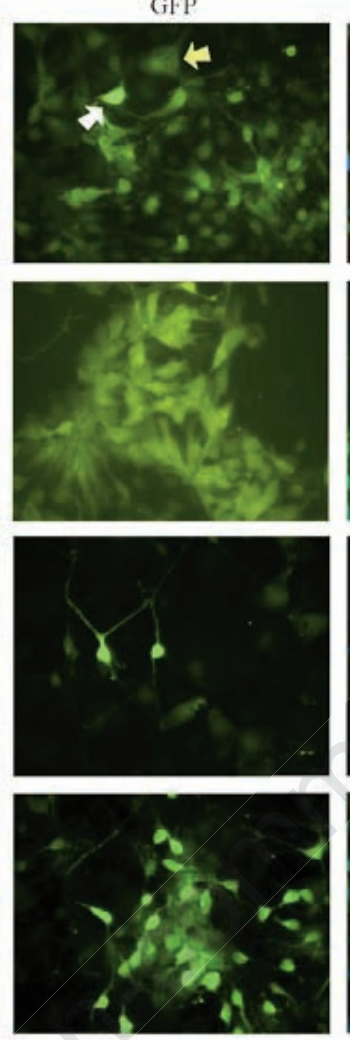

C

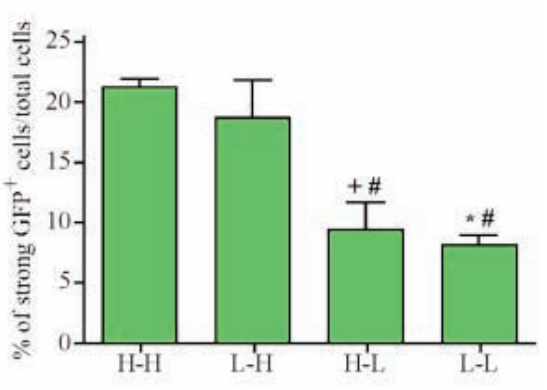

Figure 6. Effect of low $\mathrm{O}_{2}$ on Sox1-GFP+ neural precursors. Cells were cultured for 17 days in vitro and stained for green fluorescent protein (GFP) immunoreactivity. (A) Immunocytochemistry labeling of GFP on Day 17. Some cells showed intense GFP expression (white arrow, range 240-260 quantitative fluorescence calibration) and some showed less intense GFP expression (yellow arrow, range 160-180 quantitative fluorescence expression). Scale bar $50 \mu \mathrm{m}$. (B) Percentage of cells expressing GFP over total cells. There was no significant difference between groups. (C) Percentage of cells expressing intense levels of GFP over total cells. The number of cells expressing intense GFP was decreased significantly in low $\mathrm{O}_{2}$ conditions compared with high $\mathrm{O}_{2}$ during differentiation.,$+ \mathrm{P}<0.05$ compared to $\mathrm{H}-\mathrm{H}$; *, $\mathrm{P}<0.01$ compared to $\mathrm{H}-\mathrm{H} ; \#, \mathrm{P}<0.05$ compared to $\mathrm{L}-\mathrm{H}$.

rent study, mESCs were differentiated for 17 days with N2B27 and neural precursor cells were selected using puromycin and RA. Therefore, both in high and low $\mathrm{O}_{2}$ cultures of the current study, non-neural cells were rarely present from Day 12 onwards. Accordingly, there were enriched neural populations already in both $\mathrm{O}_{2}$ tensions, so the difference between low and high $\mathrm{O}_{2}$ cultures was not as pronounced as that found by Mondragon-Teran et al. However, we did observe more rapid differentiation in the current study since there were more mature GABAergic neurons in low $\mathrm{O}_{2}$ cultures. Consequently, our two studies agree that one of the effects of low $\mathrm{O}_{2}$ in $\mathrm{mESC}$ neuronal differentiation using the monolayer method is in accelerating neuronal differentiation. One study comparing the effects of oxygen tension on mouse neural stem cells derived from embryonic GE reported an effect of different $\mathrm{O}_{2}$ tensions on neuronal cell generation. ${ }^{17}$ Neuronal differentiation (measured as $\mathrm{TUJl}^{+}$cells) was most efficient in $2 \% \mathrm{O}_{2}$ than other oxygen tensions (0, 1, 4, 10 and 20\%). Similarly, hESCs proliferated under 3 and 5\% $\mathrm{O}_{2}$ tensions have been shown to have enhanced formation of EBs. ${ }^{31,32}$ In addition to neuronal differentiation from primary cells, NSCs, and ESCs, other types of cell such as osteocytes, ${ }^{33}$ platelets, ${ }^{34}$ vascular tissues, ${ }^{35}$ cartilage,${ }^{36}$ and cardiac cells ${ }^{37}$ tend to develop better in low $\mathrm{O}_{2}$ tensions. Therefore, this more rapid maturation effect seems a common phenomenon for stem cell differentiation. In support of this, in the current study, the percentage of the intense Sox1-GFP+ neural precursor population was decreased in low $\mathrm{O}_{2}$ conditions. This does not indicate that low $\mathrm{O}_{2}$ conditions inhibited neural differentiation, since the combined populations expressing both high and low levels of GFP were similar when comparing high and low $\mathrm{O}_{2}$ cultures. Therefore, it seems likely that more neural precursor cells differentiated earlier into neurons and glial cells in low $\mathrm{O}_{2}$ conditions than in high $\mathrm{O}_{2}$, maturing and down-regulating GFP at a faster rate. In a rat VM culture study, nestin ${ }^{+}$neural precursors were reduced in low $\mathrm{O}_{2}$ and markers for neurons and glial cells appeared earlier in low $\mathrm{O}_{2}$ cultures than in high $\mathrm{O}_{2}$ cultures, although there was no significant difference in the percentage of $\mathrm{TUJ}^{+}$cells different between conditions. ${ }^{12}$ The percentage of TUJ1+ neurons in our study was the same in both oxygen tensions which agrees with primary cell culture studies, ${ }^{12,15,16}$ although some studies have reported increased neuronal differentiation ${ }^{17,19}$ and some have reported decreased neuronal differentiation. ${ }^{27}$ These discrepancies in neuronal number might be due to the different cell types used, different medium, different absolute oxygen levels, and different 
incubation length. In this study, the neurons generated in low $\mathrm{O}_{2}$ appeared to be more mature since they possessed more neurites, and more GABA neurotransmitter. Other studies using precursor/ adult stem cells also described better differentiation of different neurons under low $\mathrm{O}_{2}$ conditions. Rat VM precursors produced more dopaminergic (DAergic) neurons able to release dopamine (DA). ${ }^{12,13}$ Another study reported a change in

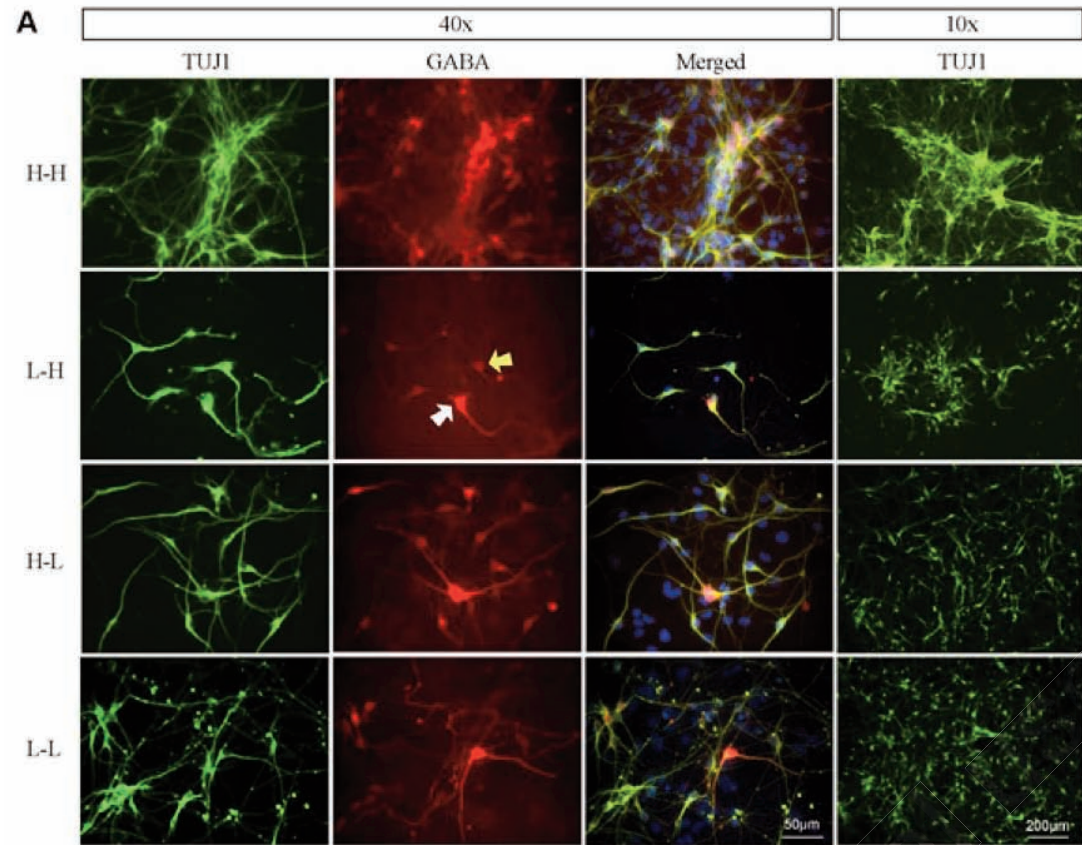

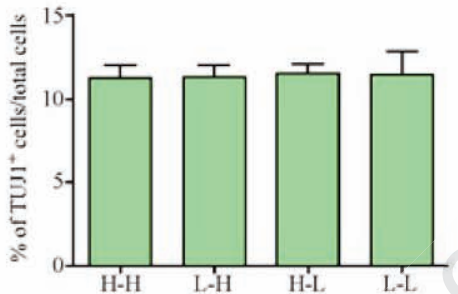

D

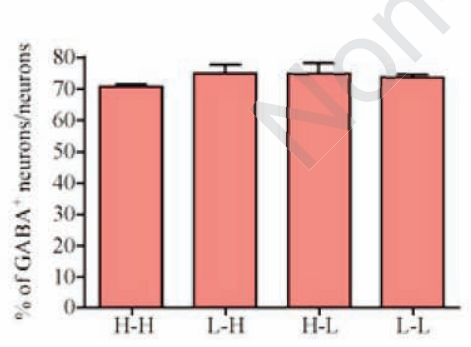

C

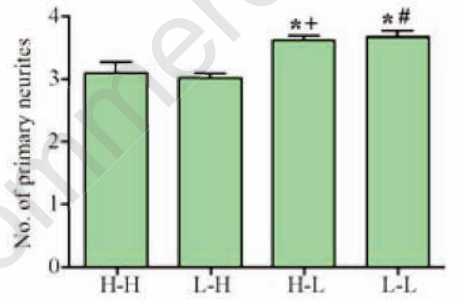

E

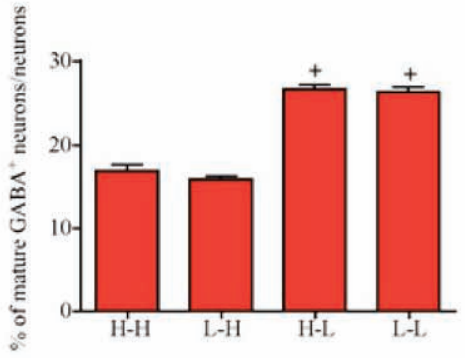

Figure 7. Effect of low $\mathrm{O}_{2}$ on neuronal and GABAergic neuronal differentiation. Cells were cultured for 17 days in vitro and labeled with TUJ1 and GABA antibodies. (A) Immunocytochemistry of TUJ1 and GABA on Day 17. Some cells showed GABA expression (white arrow, range 220-260 quantitative fluorescence calibration) and some less strong GABA expression (yellow arrow, range 100-150 quantitative fluorescence calibration). Scale bar $50 \mu \mathrm{m}$ in $40 \mathrm{x}$ and $200 \mu \mathrm{m}$ in 10x images. (B) The percentage of TUJ1+ cells over total cells. There was no significant difference between groups. (C) The number of primary neurites per neuron. There were significantly more neurites in neurons cultured in low $\mathrm{O}_{2}$ during differentiation ( $\mathrm{H}-\mathrm{L}$ and $\mathrm{L}-\mathrm{L}){ }^{*}, \mathrm{P}<\mathbf{0 . 0 5}$ compared to $\mathrm{H}-\mathbf{H} ;+, \mathrm{P}<\mathbf{0 . 0 5}$ compared to $\mathrm{L}-\mathrm{H}$; \#, $\mathrm{P}<0.01$ compared to $\mathrm{L}-\mathrm{H}$. (D) The percentage of all GABAergic neurons over total neurons. There was no significant difference between groups. (E) The percentage of neurons expressing intense GABA immunoreactivity over total neurons. Neurons expressed higher levels of GABA in cultures differentiated in low $\mathrm{O}_{2}(\mathrm{H}-\mathrm{L}$ and $\mathrm{L}-\mathrm{L}),+, \mathrm{P}<0.001$ compared to $\mathrm{H}-\mathrm{H}$ and $\mathrm{L}-\mathrm{H}$.

the neurotransmitter phenotype from GABAergic to glutamatergic ${ }^{17}$ and, in neural crest stem cells, the new appearance of a sympathoadrenal lineage. ${ }^{19}$ In low $\mathrm{O}_{2}$ cultures, expanded human SVZ cells and rat cortical progenitors produced oligodendrocytes, which were very rarely generated in high $\mathrm{O}_{2}$ cultures. ${ }^{15,16}$ One recent study generated DAergic neurons from mESCs using low $\mathrm{O}_{2}(3.5 \%)$ tension and the 5 -stage protocol. ${ }^{20}$ There was no difference in the percentage of TUJ1+ neurons between high and low $\mathrm{O}_{2}$ cultures, but there was an increase in absolute $\mathrm{TH}^{+}$cell numbers and mRNA expression of TH, Nurrl, and engrailed-1 (En-1) in low $\mathrm{O}_{2}$ conditions.

Taken together, low $\mathrm{O}_{2}(2 \%)$ tension during the proliferating period and/or differentiation period removed the $0 \mathrm{ct} 4^{+}$pluripotent stem cell population completely and lowered proliferation of mESCs. In addition, neurons differentiated in low $\mathrm{O}_{2}$ tension showed better maturation with an increased number of primary neurites, and increased levels of GABA neurotransmitter. Therefore, it might be necessary to culture mESCs in low $\mathrm{O}_{2}$ conditions to differentiate them to become GABAergic neurons to be used in cell transplantation, both to eliminate the $0 \mathrm{ct} 4^{+}$dividing stem cells and for a more enhanced and specific differentiation.

\section{References}

1. Vanderkooi JM, Erecinska M, Silver IA Oxygen in mammalian tissue: methods of measurement and affinities of various reactions. Am J Physiol 1991;260:C113150.

2. Silver I, Erecinska M. Oxygen and ion concentrations in normoxic and hypoxic brain cells. Adv Exp Med Biol 1998;454:7-16.

3. Erecinska M, Silver IA. Tissue oxygen tension and brain sensitivity to hypoxia. Respir Physiol 2001;128:263-76.

4. Rodesch F, Simon P, Donner C, Jauniaux E. Oxygen measurements in endometrial and trophoblastic tissues during early pregnancy. Obstet Gynecol 1992;80:283-5.

5. Fischer B, Bavister BD. Oxygen tension in the oviduct and uterus of rhesus monkeys, hamsters and rabbits. J Reprod Fertil 1993:99:673-9.

6. Lee HC, Wei YH. Mitochondrial biogenesis and mitochondrial DNA maintenance of mammalian cells under oxidative stress. Int J Biochem Cell Biol 2005;37:822-34.

7. Saretzki G, Armstrong L, Leake A, et al. Stress defense in murine embryonic stem cells is superior to that of various differentiated murine cells. Stem Cells 2004;22: 962-71.

8. Forsyth NR, Musio A, Vezzoni P, et al. 
Physiologic oxygen enhances human embryonic stem cell clonal recovery and reduces chromosomal abnormalities. Cloning Stem Cells 2006;8:16-23.

9. Wang FN, Thirumangalathu S, Loeken MR. Establishment of new mouse embryonic stem cell lines is improved by physiological glucose and oxygen. Cloning Stem Cells 2006;8:108-16.

10. Powers DE, Millman JR, Huang RB, Colton CK. Effects of oxygen on mouse embryonic stem cell growth, phenotype retention, and cellular energetics. Biotechnol Bioeng 2008;101:241-54.

11. Prasad SM, Czepiel M, Cetinkaya C, et al. Continuous hypoxic culturing maintains activation of Notch and allows long-term propagation of human embryonic stem cells without spontaneous differentiation. Cell Prolif 2009;42:63-74.

12. Studer L, Csete M, Lee SH, et al. Enhanced proliferation, survival, and dopaminergic differentiation of CNS precursors in lowered oxygen. J Neurosci 2000;20:7377-83.

13. Storch A, Paul G, Csete M, et al. Long-Term Proliferation and Dopaminergic Differentiation of Human Mesencephalic Neural Precursor Cells. Exper Neurol 2001;170:317-25.

14. Csete M. Oxygen in the cultivation of stem cells. Ann N Y Acad Sci 2005;1049:1-8.

15. Chen HL, Pistollato F, Hoeppner DJ, et al. Oxygen tension regulates survival and fate of mouse central nervous system precursors at multiple levels. Stem Cells 2007;25:2291-301.

16. Pistollato F, Chen HL, Schwartz PH, et al. Oxygen tension controls the expansion of human CNS precursors and the generation of astrocytes and oligodendrocytes. Mol Cell Neurosci 2007;35:424-35.

17. Horie N, So K, Moriya T, et al. Effects of oxygen concentration on the proliferation and differentiation of mouse neural stem cells in vitro. Cell Mol Neurobiol 2008;28:833-45.

18. Milosevic J, Schwarz SC, Krohn K, et al. Low atmospheric oxygen avoids maturation, senescence and cell death of murine mesencephalic neural precursors. J Neurochem 2005;92:718-29.

19. Morrison SJ, Csete M, Groves AK, et al. Culture in reduced levels of oxygen promotes clonogenic sympathoadrenal differentiation by isolated neural crest stem cells. J Neurosci 2000;20:7370-6.

20. Kim TS, Misumi S, Jung CG, et al. Increase in dopaminergic neurons from mouse embryonic stem cell-derived neural progenitor/stem cells is mediated by hypoxia inducible factor-1alpha. J Neurosci Res 2008;86:2353-62.

21. Mondragon-Teran P, Lye GJ, Veraitch FS. Lowering oxygen tension enhances the differentiation of mouse embryonic stem cells into neuronal cells. Biotechnol Prog 2009;26:1480-8.

22. Aubert J, Stavridis MP, Tweedie S, 0'Reilly M, Vierlinger K, Li M, et al. Screening for mammalian neural genes via fluorescence-activated cell sorter purification of neural precursors from Soxl-gfp knock-in mice. Proc Natl Acad Sci U S A 2003;100 Suppl 1:11836-41.

23. Ying QL, Stavridis M, Griffiths D, et al. Conversion of embryonic stem cells into neuroectodermal precursors in adherent monoculture. Nat Biotechnol 2003;21:1836 .

24. Shin E, Palmer MJ, Li M, Fricker RA. GABAergic Neurons from mouse embryonic stem cells possess functional properties of striatal neurons in vitro, and develop into striatal neurons in vivo in a mouse model of Huntington's Disease. Stem Cell Rev 2012;8:513-31.

25. Corish P, Tyler-Smith C. Attenuation of green fluorescent protein half-life in mammalian cells. Protein Eng 1999;12:1035-40.

26. Zhao T, Zhang CP, Liu ZH, et al. Hypoxiadriven proliferation of embryonic neural stem/progenitor cells-role of hypoxiainducible transcription factor-1alpha. FEBS J 2008;275:1824-34.

27. Gustafsson MV, Zheng X, Pereira T, et al. Hypoxia Requires Notch Signaling to Maintain the Undifferentiated Cell State. Developmental Cell 2005;9:617-28.
28. Lee SH, Heo JS, Han HJ. Effect of hypoxia on 2-deoxyglucose uptake and cell cycle regulatory protein expression of mouse embryonic stem cells: involvement of Ca2+ /PKC, MAPKs and HIF-1alpha. Cell Physiol Biochem 2007;19:269-82.

29. Kurosawa H, Kimura M, Noda T, Amano Y. Effect of oxygen on in vitro differentiation of mouse embryonic stem cells. J Biosci Bioeng 2006;101:26-30.

30. Cameron CM, Harding F, Hu WS, Kaufman DS. Activation of hypoxic response in human embryonic stem cell-derived embryoid bodies. Exper Biol Med 2008;233: 1044-57.

31. Ezashi T, Das P, Roberts RM. Low 02 tensions and the prevention of differentiation of hES cells. Proc Natl Acad Sci USA 2005; 102:4783-8.

32. Forsyth NR, McWhir J. Human embryonic stem cell telomere length impacts directly on clonal progenitor isolation frequency. Rejuvenation Res 2008;11:5-17.

33. Lennon DP, Edmison JM, Caplan AI. Cultivation of rat marrow-derived mesenchymal stem cells in reduced oxygen tension: effects on in vitro and in vivo osteochondrogenesis. J Cell Physiol 2001; 187:345-55.

34. Mostafa SS, Miller WM, Papoutsakis ET. Oxygen tension influences the differentiation, maturation and apoptosis of human megakaryocytes. Br J Haematol 2000;111: 879-89.

35. Hanjaya-Putra D, Gerecht S. Vascular engineering using human embryonic stem cells. Biotechnol Prog 2009;25:2-9.

36. Koay EJ, Athanasiou KA. Hypoxic chondrogenic differentiation of human embryonic stem cells enhances cartilage protein synthesis and biomechanical functionality. 0steoarthritis Cartilage 2008;16:1450-6.

37. Niebruegge S, Bauwens CL, Peerani R, et al. Generation of human embryonic stem cell-derived mesoderm and cardiac cells using size-specified aggregates in an oxygen-controlled bioreactor. Biotechnol Bioeng 2009;102:493-507. 